\title{
Geography Teachers' Opinions Regarding the Teaching Field Knowledge Test in the Public Personnel Selection Exam
}

\author{
Abdullah Türker ${ }^{1}$ \\ ${ }^{1}$ Department of Geography Education, Gazi Education Faculty, Gazi University, Ankara, Turkey \\ Correspondence: Abdullah Türker, Department of Geography Education, Gazi Education Faculty, Gazi University, \\ Ankara, 06500, Turkey. E-mail: abdullahturker82@gmail.com
}

Received: October 3, 2020

Accepted: November 15, 2020

Online Published: December 26, 2020

doi:10.5539/ies.v14n1p52

URL: https://doi.org/10.5539/ies.v14n1p52

\begin{abstract}
The number of teacher candidates is increasing as a result of the excessive quotas given to departments that train teacher candidates and the right to teach different branches with pedagogical formation certificates. Therefore it becomes compulsory to hold selection exams in teacher appointments. The exams carried out during this selection process undergo changes over time both in number and content. While exams containing questions of general knowledge, general ability, and educational sciences were used in teacher appointments in Turkey since 2002, the field knowledge test has also been applied since 2013. Geography is also one of the branches in which the field knowledge exam is applied. This study aims to evaluate the field knowledge exam according to the views of geography teachers. The study conducted in a phenomenology pattern, one of the qualitative research methods, was carried out with 25 geography teachers determined by criterion sampling methods. The data collected through semi-structured interviews were analyzed by descriptive analysis method. Direct quotations are included to increase the reliability of the research. In line with the opinions of the geography teachers, it was determined that as it increases teacher competence, taking the field knowledge exam is important and necessary. The majority opinion is that increasing the number of questions in the field knowledge exam in 2019 increased the content validity of the exam. As it caused changes in the questions, the field knowledge exam duration was considered to be excessive by some participants. According to the views of the geography teachers, undergraduate education did not coincide with the scope of the field knowledge test. It was determined that most of the candidates went to the course in the exam preparation process in order to fill the deficiencies. As a result of the research, it is recommended that the number of questions in the field knowledge test, the content validity should increase further, and the effect of the field knowledge test on the scoring basis for appointment should be further increased.
\end{abstract}

Keywords: geography teacher, field knowledge, teacher appointments

\section{Introduction}

Turkey's population is 83.1 million as of the end of 2019, and the annual growth rate was 13.9 per thousand. The 0-14 age group constitutes the $23.1 \%$ of the total population (TÜIK, 2020). Depending on the size of the young population and growth rates, the number of students is increasing in Turkey. Therefore, this situation causes an increase in the need for teachers and schools. According to the statistics of the 2019-2020 academic year, the total number of students in formal education is 18.2 million, and the number of teachers on duty is 1.1 million (MEB, 2020). The number of students and teachers in Turkey is higher than the total population of some countries (such as Finland, Belgium, and Sweden). The need for teachers is increasing day by day depending on the number of students receiving formal education, which corresponds to $21.6 \%$ of the total population. Despite the increase in the need for teachers, it is observed that problems regarding the employment of undergraduate graduates who receive teacher education have also increased. The main reason for this can be that more teacher candidates graduate than the annual need and that candidates who are not graduated from teaching undergraduate are given the right to be appointed as teachers with pedagogical formation practices. With the excess number of teacher candidates, exam practices have been initiated in teacher appointments. According to the data of ÖSYM (Student Selection and Placement Center/SSPC) (2019), 8197 candidates from the branch of Geography took the TFKT (Teaching Field Knowledge Test) exams held in 2019. Despite this number, an average of 100-150 teachers is appointed each year in the Geography branch. As such, it becomes a necessity to make an exam for teacher appointments. 
Teacher employment by the Ministry of National Education (MEB/MNE) is made through the Public Personnel Selection Examination (PPSE). PPSE is conducted in accordance with the provisions of the Procedures and Principles Regarding the Examinations for Candidates to be Assigned to Public Service for the First Time, which was put into force with the Council of Ministers Decision No. 2002/3975, dated 18.03.2002 published in the Official Gazette No. 24744, dated 03.05.2002. In the PPSE exams, tests consisting of General Knowledge (GK) and General Ability (GA) questions started to be applied in determining candidates to work in all public institutions. In addition to the GK and GA tests entered by the pre-service teachers, even though there have been changes in the number of questions over the years, Educational Sciences (ES) test was also added to measure the professional knowledge level of pre-service teachers. Until 2013, the P10 score type calculated as a result of GK + GA + ES exams for teacher candidates was used as the basis for appointment. P10 score was calculated by taking $30 \%$ of the General Ability Test, $30 \%$ of the General Knowledge Test, and $40 \%$ of the Educational Sciences Test. Despite the increasing number of teacher candidates, the Teaching Field Knowledge Test (TFKT) has been applied in addition to some branches since 2013 due to the limited number of appointment quotas and to measure the competencies of the candidates in their own branch and the education they received at the undergraduate level. In 2013, the test rates used in calculating the P121 score type, which is valid for teacher appointments, have been changed to $50 \%$ of TFKT, $20 \%$ of ES test, $15 \%$ of GK test, and $15 \%$ of GA test (Karaer et al., 2018). Since 2016, an oral exam has been applied for teacher appointments, and the P121 score type has been used as the entrance score for the oral exam. In the TFKT, which has been carried out since 2013, a 50-question exam consisting of a 40-question Field Knowledge Test and a 10-question Field Education Test were applied in all branches. As of 2019 , the number of questions in the TFKT exam has been increased from 50 to 75 , but the rates in the type of score have not been changed.

Field knowledge is defined by Shulman (1987) as knowledge and competence about concepts and phenomena related to the field. There is a need for teachers who are well-equipped in terms of field knowledge in order to raise future generations as well-equipped and conscious individuals. With the TFKT exam applied since 2013 in teacher appointments, it is aimed to measure the field knowledge competencies of teacher candidates. Çelik and Kavak (2009) examined the literature and researches about the exams applied in teacher appointments abroad and emphasized that the PPSE exam is insufficient in measuring the field knowledge of the teacher candidates and the necessity of applying a field knowledge exam. It has been emphasized in many studies that taking the TFKT exam is necessary and beneficial, as teacher candidates become better equipped in terms of field knowledge during the preparation process for the exam (Demir \& Bütüner, 2014; Uyulgan \& Akkuzu, 2015; Polatcan et al., 2016; Recepoğlu et al., 2016; Karaer et al,. 2018; Halmatov \& Kizıltaş, 2019).

In many countries, measures are taken and studies are carried out to increase the quality of teachers. PPSE-like exams applied in teacher appointments in our country are seen in Germany, Austria, France, Spain and Luxembourg, and some states of the USA. These exams can be in the form of a paper-pencil test, as well as interviews (interview) as seen in Belgium, Greece, the Netherlands, and Portugal (Gündoğdu et al., 2008, p. 36). In the state of Washington of the USA, a three-stage system has been implemented in teacher appointment applications since 2009 to eliminate candidates below professional standards. In this system, there is a written exam in which knowledge and competencies are measured, an oral examination by the administrators of the education district, and exemplary lecture practices that the administrators participate in (Jacob, 2016). It is seen that in countries that accept more students than employment needs to teaching programs, exams are made in various formats for teacher appointments (Barber \& Mourshed, 2007). Koşar et al. (2018), states that teacher selection should be carried out with a three-stage system. These stages are; Student selection examination for teacher training institutions, an examination for selection among teacher candidates, and performance evaluation throughout their professional life and ensuring continuous professional development.

In the literature, it is seen that the suggestions that the field knowledge exam should be made in the studies before the field knowledge exams are applied, coincide with the opinions of the candidates in the studies conducted with the application of the exam. The candidates who took the field knowledge exam mostly emphasize the necessity of these exams. Different opinions have been put forward regarding the scope and format of the exam in the studies. Except for the study (Sözen \& Türksever, 2018), which examined the distribution of questions related to the TFKT exam that geography teachers took, no detailed research was found. This research, which is expected to contribute to filling the gap in the literature, aims to evaluate TFKT, which is used in teacher appointments since 2013 and constitutes $50 \%$ of the oral exam entrance score after 2016, according to the opinions of Geography teachers on the topics of scope, content, validity, the impact of undergraduate education and preparation process. 


\section{Method}

\subsection{Research Model}

Qualitative research methods were used in this research. The main priority in qualitative research is to reveal and interpret how people make sense of their lives (Yıldırım \& Şimşek, 2018; Merriam, 2013). How people interpret their experiences is of great importance in qualitative research. Being together with people, conducting observations, and interviews with them in order to reveal their perception of reality will contribute to the researcher's reaching the right results. One of the qualitative research designs, phenomenology, was used in the study. Phenomenology design is a subjective approach that offers the opportunity to systematically examine daily life experiences in depth (Khan, 2014). In the phenomenology design, the researcher should know the scope of the phenomenon well in order to recognize the experiences of the participants and explain what lies in its core (Onat-Kocabıyık, 2016). This pattern allows the researcher to reveal the experiences, perceptions, feelings, and thoughts of the participants regarding the phenomenon (Khan, 2014; Padilla-Diaz, 2015; Yüksel \& Y1ldırım, 2015).

\subsection{Study Group}

In this study conducted in phenomenology design, criterion sampling was preferred, which is one of the purposeful sampling methods. According to Patton (2015), the most widely used sampling selection method is the purposeful sampling selection method, as it allows selecting the people equipped with the facts or events in order to conduct in-depth research. In the criterion sampling method, the criteria to be considered in determining the study group are determined by the researcher (Yıldırım \& Şimşek, 2018). The inclusion criteria were determined as teacher candidates who are completed undergraduate education, have a pedagogical formation certificate, and entered the TFKT in 2019 when the number of questions was increased. Since these criteria were taken into account in the selection of the study group, differences in the distribution of the participants according to gender and faculty types were ignored. General information about the study group is given in Table 1.

Table 1. Information on the study group

\begin{tabular}{lccc}
\hline & Attribute & N & $\%$ \\
\hline \multirow{2}{*}{ Gender } & Female & 20 & 80 \\
& Male & 5 & 20 \\
\hline \multirow{3}{*}{ Graduation Year } & $2018-2019$ & 14 & 56 \\
& $2016-2017$ & 5 & 20 \\
& $2014-2015$ & 5 & 20 \\
Type of faculty graduated & 2013 and before & 1 & 4 \\
\hline \multirow{2}{*}{ Education status } & Faculty of Education & 16 & 64 \\
& Faculty of Arts and Sciences & 9 & 36 \\
\hline \multirow{3}{*}{ Graduation Grade } & Underraduate & 20 & 80 \\
& Graduate & 5 & 20 \\
\hline \multirow{3}{*}{ Number of entries for the TFKT exam } & Lower than 2.50 & 1 & 4 \\
& Between 2.50 and 3.00 & 3 & 12 \\
& Between 3,01 and 3,50 & 17 & 68 \\
& Between 3,51 and 4,00 & 4 & 16 \\
\hline Total: & 1 & 5 & 20 \\
\hline
\end{tabular}

\subsection{Data Collection Tool}

Interviews are one of the main data collection methods in phenomenology studies (Büyüköztürk et al., 2012; Bogdan \& Biklen, 1998; Creswell, 2007; Yıldırım \& Şimşek, 2018). A semi-structured interview form prepared by the researcher was used in this study, which was conducted with geography teachers. Semi-structured interview forms provide the interviewees with the opportunity to express themselves (Büyüköztürk et al., 2012). One of the advantages of semi-structured interview forms is that it provides the researcher with flexibility over the questions 
during the interview (Yıldırım \& Şimşek, 2018). During the preparation process of the interview form, the scope and questions of the TFKT exam and the literature review were examined, and a question pool consisting of 15 questions was created. For the content validity of the interview form consisting of 15 questions, two faculty members working in the field of geography education, two faculty members working in the field of educational sciences, and experts in qualitative research methods were discussed. After these interviews, the opinions and recommendations of two geography teachers, who took the TFKT exams in 2018 and 2019, were also received. In the final semi-structured interview form, besides the main questions, alternative questions in cases where the problem was not understood or misunderstood, and probing questions were also prepared to be used in case of necessity. The semi-structured interview form consisting of nine questions designed to determine personal information and 10 questions designed to determine the opinions about the TFKT was piloted with two geography teachers, one female, and one male, who were not among the participants, and then the final adjustments were made. Support was received from a Turkish education specialist for the editing of the semi-structured interview form in terms of grammar.

\subsection{Data Gathering}

The data of the study were collected through personal interviews by the researcher. After informing the Geography teachers, who constitute the study group, about the purpose and method of the research, they were asked to arrange a place and time for the interview on a voluntary basis. In the study carried out, it was emphasized by the researcher that an interview and research will be conducted in accordance with ethical principles by repeating the purpose of the research to participants before the interview. Voice recording was made with the permission of the participant in the interviews, which were conducted on a voluntary basis and lasted an average of 20-30 minutes. Merriam (2013) emphasizes that the interview should be impartial to the information and opinions of the participants. During the reporting phase of the research findings, it was stated to the participants before the interview that the names of the participants would be hidden and that the quotations made from the interview data would be transferred with coding in the form of $\mathrm{T} 1, \mathrm{~T} 2, \mathrm{~T} 3 \ldots$.

\subsection{Data Analysis}

A descriptive analysis was used to analyze the data. Numbers and percentages are included in the tables prepared as a result of the descriptive analysis. In addition to the numbers and percentages given in the tables, direct quotations were made from the opinions of the participants in order to increase the reliability of the study. For the internal validity of the study, the significance of the data, and the consistency of findings within themselves were checked. Also, efforts were made to spend enough time together to make the participants feel comfortable in order to increase reliability. The reliability of the study was tried to be increased by obtaining participant confirmation as a result of the analysis of the data.

\section{Findings}

This section presents the findings obtained as a result of the analysis of the data collected with the semi-structured interview form. Findings regarding the questions are presented objectively in sub-headings, first by giving numbers and percentages on the table, and then by making direct quotations from the opinions of the participants.

\subsection{Findings Regarding Whether the TFKT Exam Is Required or Not}

As the first question of the semi-structured interview form, the opinions and justifications regarding whether they find it necessary to perform the TFKT exam in teacher appointments directed to the participants are given in Table 2.

Table 2. Geography teachers' opinions on the necessity of the TFKT exam

\begin{tabular}{|c|c|c|c|c|c|}
\hline Opinions & $\mathrm{N}$ & $\%$ & Justification & $\mathrm{N}$ & $\%$ \\
\hline \multirow{2}{*}{ Yes, it is required. } & \multirow{2}{*}{20} & \multirow{2}{*}{80} & Field knowledge is essential for teacher competence. & 18 & 72 \\
\hline & & & Subject distribution should change & 2 & 8 \\
\hline \multirow{4}{*}{$\begin{array}{l}\text { No, it is not } \\
\text { required }\end{array}$} & \multirow{4}{*}{5} & \multirow{4}{*}{20} & It's not good to be limited to 75 questions & 1 & 4 \\
\hline & & & Some branches do not take an TFKT exam. This is not fair & 1 & 4 \\
\hline & & & The field knowledge is extensive and the questions are based on rote & 1 & 4 \\
\hline & & & $\begin{array}{l}\text { It is unnecessary to have such an exam after General Knowledge }+ \text { General Ability }+ \text { Educational } \\
\text { Sciences exams. }\end{array}$ & 2 & 8 \\
\hline
\end{tabular}

As can be seen in Table 2, $80 \%$ of the participants shared the opinion that it is necessary to take the TFKT exam. 
The majority of those who held this view indicated that field knowledge is necessary for teacher competence. The statements of some of the participants who share this opinion are as follows;

"Yes, I find it necessary. Because I think that field knowledge in branch courses is important for a teacher's competence (T1)."

"I find it necessary to do it. Because I think that education, which is related to the field of education we will give students in school, is an area that needs more attention than general knowledge and general ability tests (T3)."

Participants who think that the TFKT exam should not be given express their justifications such as the exam is based on memorization and that this exam is not held in all teaching branches. The statements of some of the participants, who think that the TFKT is unnecessary, are as follows;

"No, I do not find it necessary to take the TFKT exam. Yes, this exam is done to select teachers who have the necessary equipment, but it causes many teachers to be excluded from education (T19)."

"I don't find it necessary. Because there are branches that do not have an TFKT exam, and this is not fair in terms of the branches (T6)."

3.2 Findings Regarding the 50\% Effect of the TFKT Exam on the Oral Exam Entrance Score, Which Is the Basis for Appointment

For the question about their opinions regarding the TFKT having a 50\% share in the calculation of P121, which is the oral exam entrance score, which is the basis for the contracted teacher appointment, $60 \%$ of the participants stated that this ratio is appropriate. Among the participants, $28 \%$ of the geography teachers shared the opinion that the rate should be increased, and 12\% shared the view that the rate should be decreased. Participants' views on the question are as follows;

"Studying for the exam requires a long process. The oral exam is open to immediate setbacks and depends on the initiative of the other party. That's why I think P121 should be 70\% (T1)."

"...I think it is sufficient to make only the educational sciences and TFKT exams to calculate the teaching appointment score. For example, 40\% educational sciences, 60\% TFKT (T20).”

"This rate is not less, but it deserves a higher rate considering the distribution of topics, for example; 60\% (S11).”

\subsection{Findings Regarding Increasing the Number of Questions in the TFKT Exam to 75 as of 2019}

The TFKT exam, which started in 2013, was administered as 50 questions, including 2018. The number of questions in TFKT exams has been increased to 75 questions in all branches since 2019 by ÖSYM (Student Selection and Placement Center). The views and justifications of geography teachers on this issue are given in Table 3.

Table 3. Opinions on increasing the number of TFKT exam questions

\begin{tabular}{ccccc}
\hline Opinions & $\mathrm{N}$ & $\%$ & Justification \\
\hline It was good & 22 & 88 & $\begin{array}{c}\text { Scope validity increased } \\
\text { Increased reliability }\end{array}$ \\
\hline $\begin{array}{c}\text { Should be more } \\
\text { The increase in the number of questions did not } \\
\text { change anything }\end{array}$ & 1 & 4 & 4 & $\begin{array}{c}\text { Increased and will increase the sensitivity of candidates for the } \\
\text { exam }\end{array}$ \\
\hline $\begin{array}{c}\text { The increase in the number of questions was } \\
\text { unnecessary }\end{array}$ & 1 & 4 & More questions raised more unnecessary details \\
\hline
\end{tabular}

As can be seen in Table 3,88\% of the participants consider the increase in the number of questions positively as it increases the content validity and reliability of the exam. Some of the participant views on this question are as follows:

I think increasing the number of questions allows asking questions in subjects that did not ask before, and also, the number of questions increases in subjects with fewer questions. For this reason, I think the validity of the exam has increased (T3)."

"It was very beneficial in terms of increasing the scope validity (T22)." 
One of the participants stated that the increase in the number of questions increases the candidates' exam sensitivity, and the number of questions should increase even more.

"I consider it a positive situation as the increase in the number of questions increases the sensitivity of the exams in the candidates. Increasing the number of questions even more (100 questions for example) will positively affect this sensitivity (T24)."

Another geography teacher stated that the increase in the number of questions is not positive. As a justification for this, the participant states that it will cause more questions based on rote and dealing with questions that will never be faced in professional life.

"Increasing the number of questions means more memorization and more details. It means that you will occupy your memory for a while with the information you will most likely forget when your appointment is realized (T9)."

\subsection{Findings Regarding 75 Questions with Duration of 120 Minutes in the TFKT Exam Since 2019}

It was decided to apply the TFKT exam consisting of 50 questions with duration of 75 minutes from 2013 to 2018 , and 75 questions with duration of 120 minutes since 2019. Most of the participants, regarding the increase in the number of questions by $50 \%$, considered it a positive practice as it increased the content validity. The opinions of the participants regarding the 120 minutes given for 75 questions; $80 \%$ shared the opinion that the time was sufficient, while $20 \%$ stated that the time was too long, and shortening it would be more beneficial. Among the participants who stated that the time was too long, $12 \%$ of them stated that they changed the answers when they examined the questions again because they were not allowed to leave the exam until the end of the time given for the exam, and this reduced the exam net. Regarding this question, the opinions of some of the participants who stated that the exam duration should be shortened are as follows:

"I think the exam duration is too long. Leaving before the end of the exam duration is not allowed. During this time, we have the opportunity to think a lot, and we give up and change what we know right with exam psychology. Exam duration reduces the validity of the exam (T7)."

\subsection{Findings Regarding the Content Validity of the TFKT Exam}

The opinions and justifications of the geography teachers participating in the study regarding the content validity of the TFKT exam are given in Table 4.

Table 4. Opinions regarding the content validity of the TFKT exam

\begin{tabular}{|c|c|c|c|c|c|}
\hline Opinions & $\mathrm{N}$ & $\%$ & Justification & $\mathrm{N}$ & $\%$ \\
\hline \multirow{4}{*}{ Scope validity is good } & \multirow{4}{*}{15} & \multirow{4}{*}{60} & Appropriate after increasing the number of questions & 7 & 28 \\
\hline & & & The scope varies over the years & 4 & 16 \\
\hline & & & Exam coverage is good but our level of knowledge is low & 2 & 8 \\
\hline & & & Quality and selective questions & 2 & 8 \\
\hline \multirow{4}{*}{ Scope validity is not good } & \multirow{4}{*}{9} & \multirow{4}{*}{36} & Based on rote & 3 & 12 \\
\hline & & & The scope is too broad, it should be narrowed down & 3 & 12 \\
\hline & & & There are unnecessary questions & 2 & 8 \\
\hline & & & Questions should be in line with the middle-school education curriculum & 1 & 4 \\
\hline No idea & 1 & 4 & & & \\
\hline
\end{tabular}

As can be seen in Table 4, $60 \%$ of the participants shared the opinion that the content validity of the TFKT exam is good. While the participants who shared this view stated that increasing the number of questions to 75 positively affected this validity, four participants drew attention to the changes between the years.

"There were a few very detailed questions in the exam I took in 2018, apart from that, the measurement levels of the questions were good. There were questions at easy-medium-difficult levels, and the content validity was sufficient (T4)."

The nine participants, who shared the view that the content validity of the TFKT exam was not good, drew attention to issues such as the wide scope of the exam and the excess of rote questions. Some of the opinions of the participants on the subject are as follows:

"Geography field is very wide and there are many topics. It is related to many other fields. For this reason, some subjects may require detailed information other than geography field knowledge. This situation brings out the 
luck factor in reflecting the truth. Therefore, I do not think the scope and level of measurement are valid (T1)."

One of the teachers, who shared the opinion that the content validity of the exam was not good, stated that the subjects at the high school curriculum level should be emphasized in the TFKT exam.

"I believe that it would be more beneficial to make the TFKT exam with an emphasis on high school curriculum subjects (T19)."

\subsection{Findings Regarding the Most Difficult Questions in the TFKT Exam}

One of the issues that are frequently mentioned after the TFKT exam in all branches is the difficulty level of some questions. The geography teachers' answers given to the question of which subject they consider the questions as more difficult are given in Table 5 .

Table 5. Opinions regarding the most difficult questions in the TFKT exam

\begin{tabular}{ccccccc}
\hline Opinion & N & $\%$ & Justification & $\%$ \\
\hline Physical Geography & 10 & 40 & $\begin{array}{r}\text { Cartography, Climatology, and Geomorphology is very detailed } \\
\text { Our undergraduate education is insufficient }\end{array}$ & $\begin{array}{c}16 \\
24\end{array}$ \\
\hline Human and Economic Geography & 10 & 40 & Updating information every year & The questions are detailed, a lot of concepts & 6 & 24 \\
\hline Regions and Countries & 3 & 12 & The topic is broad, the questions are detailed & 3 & 12 \\
\hline Field Education & 2 & 8 & I didn't work because it was easy & 4 & 4 \\
\hline
\end{tabular}

As can be seen in Table 5, the rate of the participants, who state that the questions about Physical Geography are difficult, and the questions about Human-Economic Geography are difficult were the same. Participants cited the inadequacy of undergraduate education, the abundance of up-to-date information in the questions, and the inclusion of too much detail as the reasons for evaluating the questions about the subjects as difficult. Some of the opinions of the participants on the subject are as follows:

"Since there are topics that need to be updated every year and there is a lack of academic knowledge, humanities subjects are more challenging (T1)."

"Questions in the subject of climatology can be challenging from time to time. Because when you have a deficiency in theoretical knowledge, there may be problems in solving the problem (T16)."

Due to the insufficiency of their undergraduate education, $12 \%$ of the participants evaluated the questions under the main title of regions and countries as difficult.

"I mostly have problems in Regional Geography. I think the reason is that I could not get a well-equipped education on this subject during my university education (T20)."

Two participants stated that they had difficulties in field education questions that constitute $20 \%$ of the TFKT exam. Participants cited their underestimation of the field education part and their lack of attention as a reason for this situation.

"The final 15-question field education part challenges me. The reason for this is that I could not internalize the skills in that part, and I had an attention deficit (T7)."

"I had difficulty with questions about the teaching program. Thinking it was easy, I spent less time studying (T4)."

\subsection{Findings Regarding the Distribution of the Questions to the Topics in the TFKT Exam}

The opinions of the participants regarding the distribution of the questions in the exam are given in Table 6 . 
Table 6. Opinions about the distribution of the TFKT exam questions to the topics

\begin{tabular}{|c|c|c|c|c|c|}
\hline Opinion & $\mathrm{N}$ & $\%$ & If you were authorized, what changes would you make? & $\mathrm{N}$ & $\%$ \\
\hline \multirow{2}{*}{ Appropriate } & \multirow{2}{*}{15} & \multirow{2}{*}{60} & I would focus on questions about physical geography & 5 & 20 \\
\hline & & & No need to change anything & 10 & 40 \\
\hline \multirow{3}{*}{ Not appropriate } & \multirow{3}{*}{10} & \multirow{3}{*}{40} & Questions should be distributed equally & 5 & 20 \\
\hline & & & I would focus on the subjects to be used while teaching in middle school education & 2 & 8 \\
\hline & & & Field education questions should be reduced & 3 & 12 \\
\hline
\end{tabular}

As can be seen in the table above, $60 \%$ of the participants shared the opinion that the question-subject distribution was appropriate. While most of the participants expressing this view did not suggest any changes, five participants shared the view to increase the physical geography questions.

"I would concentrate more on climatology and geomorphology. In the humane geography part, I would add more reasoning questions instead of rote questions. In the field education part, there are generally questions about Teaching Methods and Techniques, and I think that other educational sciences courses should be included in this part (T17)."

The participants who stated that the question-subject distribution was not appropriate, expressed their suggestions to make changes such as adding questions in equal amounts from all subjects in the exam and reducing the field education questions.

"I find it more appropriate to ask an equal number of questions on each subject. It is not possible to separate the lessons in geography as important or unimportant. In addition, it causes the subjects with a low number of questions to be ignored and the subjects with a high number of questions to be considered excessively (T16)."

3.8 Findings Regarding the Participants' Undergraduate Education's Adequacy to Answer the Questions in the TFKT

Regarding the adequacy of geography teachers' undergraduate education in terms of meeting the questions in the TFKT exam, $36 \%$ of the participants stated that their undergraduate education inadequate, $36 \%$ partially adequate, $16 \%$ mostly adequate, and $12 \%$ adequate. Some of the opinions of the participants on the subject are as follows:

"I did not see its benefit very much (T7)."

"Not exactly convenient (T19)."

"Absolutely not. Undergraduate is much easier and superficial, besides this exam (T9)."

In addition, addressed to the participants, "Which courses you took during your undergraduate period made more contribution to the TFKT process?" $64 \%$ of the participants stated that Physical geography lessons are more beneficial. While $16 \%$ of the participants stated that they benefited from most lessons, $8 \%$ stated that they did not benefit from most of the lessons.

"I have benefited greatly from the physical geography lessons (T2)."

"Land Geography, Political Geography, and Climatology, I have seen no use of anything other than these (T6)."

\subsection{Findings Regarding Taking a Course While Preparing for the TFKT Exam}

As in every exam process, since 2013, when the TFKT exam started to be held, exam preparation publications and courses have been started intended for TFKT. Participants' status of attending the course in the preparation process for the exam and their reasons are given in Table 7. 
Table 7. Opinions about whether/not to attend the course during the TFKT exam preparation process

\begin{tabular}{|c|c|c|c|c|c|}
\hline Opinion & $\mathrm{N}$ & $\%$ & Justification & $\mathrm{N}$ & $\%$ \\
\hline \multirow{4}{*}{ Yes } & \multirow{4}{*}{16} & \multirow{4}{*}{64} & Has covered my lack of knowledge & 9 & 36 \\
\hline & & & Guiding & 3 & 12 \\
\hline & & & Motivating & 3 & 12 \\
\hline & & & Made my shortcomings aware & 1 & 4 \\
\hline \multirow{5}{*}{ No } & \multirow{5}{*}{9} & \multirow{5}{*}{36} & Lack of qualified instructor to teach TFKT & 2 & 8 \\
\hline & & & No courses & 2 & 8 \\
\hline & & & Online courses are more efficient & 1 & 4 \\
\hline & & & I find it unnecessary & 2 & 8 \\
\hline & & & Waste of time & 2 & 8 \\
\hline
\end{tabular}

As can be seen in Table 7, 64\% of the participants attended the course during the preparation process for the TFKT. Among the reasons for attending the course, participants stated that the course help to eliminate the lack of knowledge and that they are guiding and motivating.

"The only effect regarding the exam is that it helps with time scheduling and it is a motivating environment for study. Apart from that, the teachers are not wonderful, their field competence is only 1 in 10 of our professors at the university, but their efforts are admirable (T2)."

"It has been a complement to my undergraduate education. I learned how to study for the exam (S6)."

"First of all, it was important for discipline. Also, it was effective for me to realize where I had shortcomings (T20)."

Nine participants, who declared that they did not attend a course during the preparation for the TFKT exam, stated their justifications as lack of qualified instructors, lack of course in their places, and waste of time.

"As my working hours were too long, I think it would not be efficient for me to attend a course after work, so I decided to study myself (T19)."

"I am getting support through the online education process. More effective (T22)."

\section{Conclusion and Recommendations}

Considering the results of this study, which is conducted in the phenomenology pattern, one of the qualitative research methods, $80 \%$ of the participants stated that it is necessary to take the TFKT exam. Geography teachers, who stated that the exam was required, noted that the field knowledge is necessary for teacher competence as a justification. Similarly, as a result of the research conducted by Erdem and Soylu (2014) with teacher candidates, $75 \%$ of the participants stated that their field knowledge should also be tested in teacher selection. When the relevant literature is examined, many studies will be found that state that a teacher needs a good field knowledge as well as general knowledge and pedagogical knowledge for effective teaching (Baki, 1997; Ball, 1988, 1990; Cankoy, 2010; Davis \& Simmt, 2006; Demirel, 1999; Hill et al., 2005; Shulman, 1986, 1987; Tchoshanov, 2011; Wilson et al., 1987). As a result of the research conducted with social studies teacher candidates by Demir and Bütüner (2014), it was revealed that all participants had a common view that the field examination was a late practice and would be beneficial in appointing teachers with high field knowledge. In the study by Karaer et al. (2018), the teacher candidates shared the opinion that if an exam is to be held for appointments, this exam should only be TFKT. In studies conducted by Uyulgan and Akkuzu (2015), Polatcan et al. (2016), Recepoğlu et al. (2016), and Halmatov and Kızıltaş (2019), participants expressed a positive opinion on the TFKT exam, stating that it increases teacher competence in terms of field knowledge. Sözcü (2020), examined the professional skill competencies of geography teachers and concluded that the teachers who have low professional seniority, that is, teachers appointed with TFKT, have high professional skills as much as experienced teachers. This result can be evaluated as the positive effects of the TFKT.

In the study, $20 \%$ of the participants stated that the exam is unnecessary because the TFKT exam questions are rote-based and are not conducted in all teaching branches. The results that the field exam is unnecessary, coincide with the results of the research conducted by Şahin et al. (2015) with classroom teacher candidates. In the study conducted by Şahin and Demir (2016), Turkish teacher candidates stated that the TFKT exam was unnecessary due to the presence of rote-based questions, the low number of questions, and the low level of differentiation.

From 2013 to 2018, the exam had 50 questions. By the year 2019, the number of questions increased to $75,88 \%$ of the participants positively evaluated the increase of the number of questions as it increases the content validity of 
the exam. This result coincides with the Demir and Bütüner's (2014) research, which concludes the 50-question Field knowledge exam did not meet the scope, and the number of questions should be increased. In the study conducted by Karaer et al. (2018), teacher candidates stated that the level of field knowledge cannot be measured with 50 questions. This result supports that the increase in the number of questions is positive.

Regarding increasing the duration of the exam from 75 minutes to 120 as the number of questions increased to 75 in $2019,80 \%$ of the participants stated that the time is sufficient. However, $20 \%$ of the participants stated that they made changes in the answers because the time was too long, and exit was not allowed. Since most of the TFKT exam questions are knowledge-level questions and do not require any process such as interpretation or analysis, it can be said that the excess of time will play a role in returning and changing the answer. In the research conducted by Karaer (2019), it was revealed that the questions related to Analytical Chemistry in PPSE/TFKT between 2013 and 2018 were prepared in sub cognitive dimensions rather than metacognitive dimensions. The questions and durations in the TFKT exams were applied equally in all branches between 2013 and 2018. However, upon the complaints that the time is too long in the liberal arts and not sufficient in the STEM, as of 2019, it was decided to apply 75 questions as 120 minutes in liberal arts (such as geography, history, philosophy) and 75 questions as 150 minutes in STEM (such as mathematics, physics, chemistry). Despite this change in duration, it is seen that some geography teachers still suffer from excess time.

Participants stated that they had difficulties in physical and humane geography questions due to reasons such as insufficient undergraduate education, too much detailed, and up-to-date information. Regarding the question-subject distribution of the TFKT exam, $60 \%$ of the participants did not suggest a change in the question-subject distribution, indicating that it was appropriate. In their research, where they examine the distribution of questions in PPSE Geography TFKT, Sözen and Türksever (2019), emphasizes the difference between education and literature faculties undergraduate programs, especially in terms of meeting the questions in TFKT. In the study, it was stated that faculties of literature are more advantageous than education faculties in terms of the level of meeting the questions about physical geography.

Regarding the adequacy of geography teachers' undergraduate education in terms of meeting the questions in the TFKT exam, $36 \%$ of the participants stated that their undergraduate education inadequate, $36 \%$ partially adequate, $16 \%$ mostly adequate, and $12 \%$ adequate. In the study conducted by Demir and Bütüner (2014) with social studies teacher candidates, the participants stated that undergraduate education was insufficient for the field exam due to the lack of interest of the lecturers or their lack of mastery of the course. Likewise, Şahin et al. (2015) concluded that the courses taken in undergraduate education were insufficient in the field exam. Similarly, in Şahin and Demir (2016)'s research, it was concluded that the scope of the field exam and undergraduate course contents did not match. Çelik (2016) stated that the differences in elective courses at universities negatively affect the content validity of the exam. As a result of their research conducted with visual arts teacher candidates, Y1lmaz et al. (2018) stated that the application of the TFKT exam will increase the interest in undergraduate field and field education courses and increase the quality of teachers.

Due to reasons such as courses are guiding, motivating, and eliminating lack of knowledge, $64 \%$ of the participants attended the course during the preparation process for the TFKT. Nine participants, who did not attend a course during the preparation for the TFKT exam, stated their justifications as lack of qualified instructors, lack of course in their places, and waste of time. In the study conducted by Karaer et al. (2018), it was determined that teacher candidates had to attend a course during the preparation for PPSE and TFKT exams. Teacher candidates' justifications were the difficulty of carrying out this process without support, the opportunity to find answers to their questions, and the inadequacy of undergraduate education. In the study conducted by Atav and Sönmez (2013), it is concluded that teacher candidates need course/private tutoring support to be successful in the PPSE exam.

Based on the results of the research, it is clear that, due to its contribution to increasing teachers' content knowledge, the TFKT exams, which have been conducted since 2013, are necessary and should continue. When this research, conducted with geography teachers, and the studies in the literature are examined, it is seen that there is a discrepancy between undergraduate education and the scope of the exam. Of course, the aim of undergraduate education is not to prepare the student for the exam. However, due to the differences in the curriculum between the faculties and especially the differences between the teaching staff potential, the fact that the course titles are the same but not transferred at the same level differentiates the readiness levels of teacher candidates. This situation has a great impact on the candidates' exam preparation processes and exam success.

The following headings are recommended, in line with the results given above.

1) Increasing the number of similar researches on the scope and format of the exam, with the candidates who took 
the exam in all branches where the TFKT exam is applied, will also guide the implementing institutions regarding the exams.

2) The rate of impact of the TFKT exam on the score that is the basis for teacher appointments can be further increased. This will also increase the importance of undergraduate education for teacher candidates. In addition, the knowledge they have acquired during the field exam preparation process will enable teachers to be better equipped.

\section{References}

Atav, E., \& Sönmez, S. (2013). Öğretmen adaylarının kamu personeli seçme sınavına (KPSS) ilişkin görüşleri. Hacettepe Üniversitesi Ĕ̈itim Fakültesi Dergisi, Özel Sayı(1), 1-13.

Baki, A. (1997). Çağdaş gelişmeler ışığında matematik öğretmenliği eğitimi programları. Eğitim ve Bilim, 21(103), 46-54.

Ball, D. L. (1988). Knowledge and reasoning in mathematical pedagogy: Examining what prospective teachers bring to teacher education (Doctoral dissertation, Michigan State University, East Lansing).

Barber, M., \& Mourshed, M. (2007). How theworld'sbest-performing school systems comeout on top. London: McKinseyand Company.

Bogdan R. C., \& Biklen, S. K. (1998). Qualitative research for education: An introduction to theory and methods (3rd ed.). Boston: Allyn and Bacon.

Büyüköztürk, Ş., Kılıç-Çakmak, E., Akgün, Ö. E., Karadeniz, Ş., \& Demirel, F. (2012). Bilimsel Araştırma Yöntemleri (Geliştirilmiş 13. baskı). Ankara: Pegem Akademi.

Cankoy, O. (2010). Mathematics teachers' topic-specific pedagogical content knowledge in the context of teaching a0, 0! and a $\div 0$. Educational Sciences: Theory\&Practice, 10(2), 749-769.

Çelik, İ. (2016). Okul öncesi öğretmen adaylarının ve öğretmenlerinin öğretmenlik alan sınavına ilişkin görüşlerinin incelenmesi. EKEV Akademi Dergisi, 20(67), 163-187. https://doi.org/10.17753/Ekev660

Çelik, K., \& Kavak, Y. (2009). Eğitim fakülteleri ve KPSS-öğretmenlik sınavı sonuçları üzerine bir çalışma. Türkiye'nin Öğretmen Yetiştirme Çıkmazı Ulusal Sempozyumu, Başkent Üniversitesi, Ankara.

Creswell, J. W. (2007). Qualitative Inquiry and Research Design: Choosing Among Five Approaches (2nd ed.). Thousand Oaks, CA: Sage.

Davis, B., \& Simmt, E. (2006). Mathematics-for-teaching: An ongoingin vestigation of the mathematics that teachers (needto) know. Educational Studies in Mathematics, 61, 293-319. https://doi.org/10.1007/s10649-006-2372-4

Demir, S., \& Bütüner, K. (2014). Sosyal bilgiler öğretmen adaylarının alan sınavına yönelik görüşlerinin incelenmesi. Mersin Üniversitesi Ĕ̈itim Fakültesi Dergisi, 10(2), 113-128.

Demirel, Ö. (1999). Planlamadan değerlendirmeye ögretme sanatı. Ankara: PegemA Yayıncılık.

Erdem, E., \& Soylu, Y. (2013). Öğretmen Adaylarının KPSS ve Alan Sınavına İlişkin Görüşleri. Çankırı Karatekin Üniversitesi Sosyal Bilimler Enstitüsü Dergisi, 4(1), 223-236.

Gündoğdu, K., Çimen, N., \& Turan, S. (2008). Öğretmen adaylarının kamu personeli seçme sınavına (KPSS) ilişkin görüşleri. Ahi Evran Üniversitesi Kırşehir Ĕ̈itim Fakültesi Dergisi (KEFAD), 9(2), 35-43.

Halmatov, M., \& Kızıltaş, E. (2019). Okul öncesi öğretmen adaylarının alan sınavı ile ilgili görüşleri. İlköğretim Online, 18(2), 878-892. https://doi.org/10.17051/ilkonline.2019.562070

Hill, H. C., Rowan, B., \& Ball, D. L. (2005). Effects of teachers' mathematical know ledge for teaching on student achievement. American Educational Research Journal, 42(2), 371-406. https://doi.org/10.3102/00028312042002371

Jacob, B. A. (2016). The power of teacher selection to improve education. Economic Studies at Brookings. Evidence Speaks Report, 1(12).

Karaer, H. (2019). Yenilenmiş bloom taksonomisine göre soru analizi (KPSS/ÖABT-analitik kimyayla ilişkili sorular). Kastamonu Education Journal, 27(6), 2583-2596. https://doi.org/10.24106/kefdergi.3455

Karaer, H., Karaer, F., \& Kartal, E. (2018). Kamu personeli seçme sınavındaki öğretmenlik alan bilgisi testine yönelik öğretmen adaylarının görüşleri. Erciyes Journal of Education, 2(2), 40-58. https://doi.org/10.32433/eje.448155 
Khan, S. N. (2014). Qualitative research method-Phenomenology. Asian Social Science, 10(21), 298-310. https://doi.org/10.5539/ass.v10n21p298

Koşar, D, Er, E., Koşar, S., \& Kılınç, A. (2018). Öğretmen atamalarında sözlü sınav uygulamasının değerlendirilmesi: Atanan ve atanamayan öğretmen adaylarının görüşlerine dayalı nitel bir analiz. Milli Ĕ̈itim Dergisi, 47(218), 135-162.

MEB. (2020). Millî eğitim istatistikleri örgün eğitim 2019-2020. Retrieved from https://sgb.meb.gov.tr/meb_iys_dosyalar/2020_09/04144812_meb_istatistikleri_orgun_egitim_2019_2020. pdf

Merriam, S. (2013). Nitel araştırma (Çev. Ed. S. Turan). Ankara: Nobel.

Onat-Kocabıyık, O. (2016). Olgubilim ve gömülü kuram: Bazı özellikler açısından karşılaştırma. Trakya Üniversitesi Ĕgitim Fakültesi Dergisi, 6(1), 55-66.

ÖSYM. (2019). 2019 KPSS Lisans ÖABT sinavina giren aday saylarl. Retrieved from https://dokuman.osym.gov.tr/pdfdokuman/2019/KPSS/sayisalbilgiler29082019.pdf

Padilla-Diaz, M. (2015). Phenomenology in educational qualitative research: Philosophy as science or philosophical science. International Journal of Educational Excellence, 1(2), 101-110. https://doi.org/10.18562/IJEE.2015.0009

Patton, M. Q. (2015). Qualitative research \& evaluation methods: integration theory and practice (4th ed.). Thousand Oaks, CA: Sage.

Polatcan, M., Öztürk, İ., \& Saylık, A. (2016). Öğretmen adaylarının kamu personeli seçme sınavına (KPSS) ilişkin görüşleri. Route Educational and Social Science Journal, 3(1), 126-138. https://doi.org/10.17121/ressjournal.438

Recepoğlu, E., Akgün, K., \& Aksu, S. (2016). Okul öncesi öğretmen adaylarının KPSS alan sınavına ilişkin görüşleri. Kastamonu Eğitim Dergisi, 24(5), 2537-2548.

Resmi Gazete. (2002). Kamu görevlerine ilk defa atanacaklar için yapılacak sınavlar hakkında genel yönetmelik. Retrieved from http://www.resmigazete.gov.tr/eskiler/2002/05/20020503.htm

Şahin, Ç., \& Demir, F. (2016). Türkçe Öğretmen Adaylarının Türkçe Öğretmenliği Alan Sınavına Yönelik Algiları. Eğitimde Kuram ve Uygulama, 12(4), 979-992.

Şahin, Ç., Arcagök, S., Girgin Sarıdaş, D., \& Demir, M. (2015). Sınıf öğretmeni adaylarının sınıf öğretmenliği alan sınavına yönelik görüşleri. Bartın University Journal of Faculty of Education XIV. Uluslararası Katılımlı Sinıf Öğretmenliği Ĕgitimi Sempozyumu (21-23 Mayıs 2015) Özel Saylsl, 183-194. https://doi.org/10.14686/BUEFAD.2015USOSOzelsayi13209

Shulman, L. S. (1986). Thosewhounderstand: Knowledge growth in teaching. Educational Researcher, 15(2), 4-14. https://doi.org/10.3102/0013189X015002004

Shulman, L. S. (1987). Knowledge andteaching: Foundation of thenew reform. Harvard Educational Review, 57(1), 1-22. https://doi.org/10.17763/haer.57.1.j463w79r56455411

Sözcü, U. (2020). Türkiye'de coğrafya araştırmaları. In F. Akbaş, \& E. Atış (Eds.), Coğrafya öğretmenlerinin mesleki beceri yeterliklerinin incelenmesi (pp. 255-272). Ankara: Gazi Kitabevi.

Sözen, E., \& Türksever, Ö. (2019). KPSS coğrafya öğretmenlik alan bilgisi testi (ÖABT) soru dă̆ılımlarının incelenmesi. Türkiye Sosyal Araştırmalar Dergisi, 23, 73-84.

Tchoshanov, M. A. (2011). Relationship between teacher know ledge of concepts and connections, teaching practice, and student achievement in middle grades mathematics. Educational Studies in Mathematics, 76, 141-164. https://doi.org/10.1007/s10649-010-9269-y

TÜIK. (2020). Adrese Dayalı Nüfus Kayıt Sistemi Sonuçlarl, 2019. Retrieved from http://www.tuik.gov.tr/PreHaberBultenleri.do?id=33705

Uyulgan, M., \& Akkuzu, N. (2015). Öğretmen adaylarının gözünden nitelikli öğretmen seçimi: Ortaöğretim fen ve matematik alanları öğretmenliklerinin durumu. Kastamonu Eğitim Dergisi, 23(3), 917-940.

Wilson, S. M., Shulman, L. S., \& Richert, A. (1987). 150 different ways of knowing: Representations of knowledge in teaching. In J. Calderhead (Ed.), Exploring teachers' thinking (pp. 104-124). Sussex, England: Holt, Rinehart \& Winston. 
Yıldırım, A., \& Şimşek, H. (2018). Sosyal bilimlerde nitel araştırma yöntemleri (11. baskı). Ankara: Seçkin. https://doi.org/10.18020/kesit.1279

Yılmaz, M., Laçinbay, K.., Elmas, H., \& Yağc1, N. (2018). Görsel sanatlar öğretmeni istihdamında öğretmenlik alan bilgisi testinin gerekliliği ve KPSS'ye yönelik alg1 ölçeği geliştirme çalışması. E-Kafkas Eğitim Araştırmaları Dergisi, 5(2), 40-49. https://doi.org/10.30900/kafkasegt.435702

Yüksel, P., \& Yıldırım, S. (2015). Theoretical frameworks, methods, and procedures for conducting phenomenological studies in educational settings. Turkish Online Journal of Qualitative Inquiry, 6(1), 1-10. https://doi.org/10.17569/tojqi.59813

\section{Copyrights}

Copyright for this article is retained by the author(s), with first publication rights granted to the journal.

This is an open-access article distributed under the terms and conditions of the Creative Commons Attribution license (http://creativecommons.org/licenses/by/4.0/). 